\title{
PERANAN MENWA DALAM CHARACTER BUILDING UNTUK MENDUKUNG KEUNGGULAN BERSAING DI INDUSTRI 4.0
}

\author{
Raden Didiet Rachmat Hidayat ${ }^{1}$, Sandriana Marina ${ }^{2}$, Aisyah Rahmawati ${ }^{3}$, Reza Fauzi \\ Jayasakti $^{4}$, Lira Agusinta ${ }^{5}$ \\ ${ }^{1}$ Institut Transportasi dan Logistik Trisakti \\ ${ }^{2}$ Institut Transportasi dan Logistik Trisakti \\ ${ }^{3}$ Institut Transportasi dan Logistik Trisakti \\ ${ }^{4}$ Institut Transportasi dan Logistik Trisakti \\ ${ }^{5}$ Institut Transportasi dan Logistik Trisakti
}

didiet.hidayat@yahoo.com, sandrianamarina@yahoo.co.id,yas_syh@yahoo.com,reza.jayasakti@gmail.com, agusinta@yahoo.com

\begin{abstract}
Abstrak
Era industri 4.0 yang bercirikan smart automation yang dipicu dengan pengembangan Information and Communication Technologies (ICT) telah merubah pola bisnis di dunia dari offline menjadi online. Kesiapan mahasiswa sebagai generasi muda untuk menghadapi era industri tersebut harus dipersiapkan dari sekarang. Kesiapan SDM merupakan suatu persyaratan dasar untuk dapat bersaing di pasar bagi mahasiswa setelah menamatkan pendidikan. Persaingan bergeser menjadi manusia melawan mesin. Salah satu pelatihan soft skill dapat diterapkan kepada mahasiswa melalui UKM MENWA. Penelitian ini dilakukan dengan menggunakan pendekatan kualitatif. Hasil yang didapat adalah character building yang berbasis leadership, problem solving dan collaboration merupakan suatu competitive advantage bagi mahasiswa dalam era industri ini. Character building sebagai suatu proses atau usaha yang dilakukan untuk membina, memperbaiki dan membentuk tabiat, watak, sifat kejiwaan, akhlak, insan manusia sehingga menunjukkan perangai dan tingkah laku yang baik berlandaskan nilai Pancasila serta membutuhkan suatu konsistensi swa disiplin. Di sisi lain, character building berupa swa disiplin yang sudah terbentuk juga dapat dipergunakan untuk menurunkan radikalisme - sebagai paham atau aliran yang menginginkan perubahan atau pembaharuan social dan politik dengan cara kekerasan atau drastis - di institusi pendidikan MENWA mempunyai peranan penting dalam mengimplementasikan pendidikan character building sebagai soft skill yang telah diperoleh dengan kebutuhan di era industri 4.0.
\end{abstract}

Kata kunci: resimen mahasiswa, character building, soft skill, competitive advantage

\section{PENDAHULUAN}

Revolusi industri telah berkembang dari era industri 1.0 menjadi era industri 4.0. Dimulai dari era industri 1.0 di tahun 1800 yang memakai teknologi mechanisasation dan mechanical power generation. Disusul oleh era industri 2.0 di tahun 1900 yang bertumpu kepada electrification dan industrialisasation. Sedangkan era industri 3.0 yang berkembang mulai tahun 1960 bersandar kepada digitalisasion dan electronic automation. 
Perkembangan yang terbaru dari revolusi industri adalah industri 4.0 yang mempunyai ciri smart automation yang dipicu dengan pengembangan Information and Communication Technologies (ICT). Era industri ini dimulai dari negara Jerman di tahun 2011 pada acara Hannover Fair. Era ini sangat mengedepankan penggunaan internet dan Internet of Things (IoT).

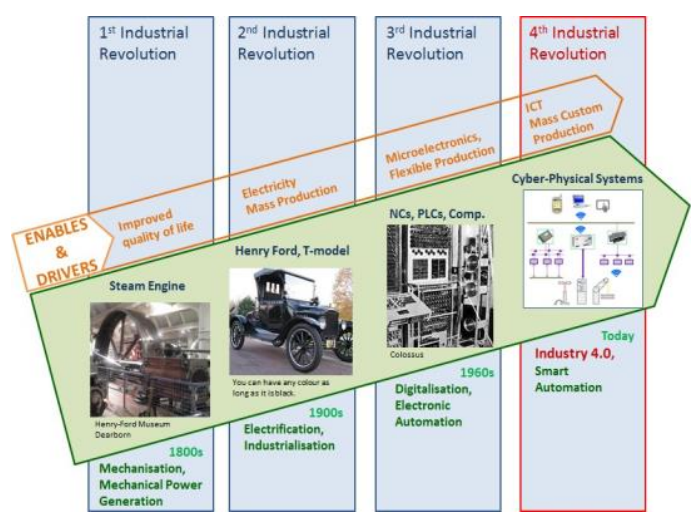

Gambar 1 Tahapan Revolusi Industri

Pengaruh era terakhir ini sangat terasa di dunia dan juga di Indonesia. Ditenggarai dengan menjamurnya bisnis online, platform, cashless payment. Beberapa bisnis offline juga mengalami dampak dari era bisnis ini.

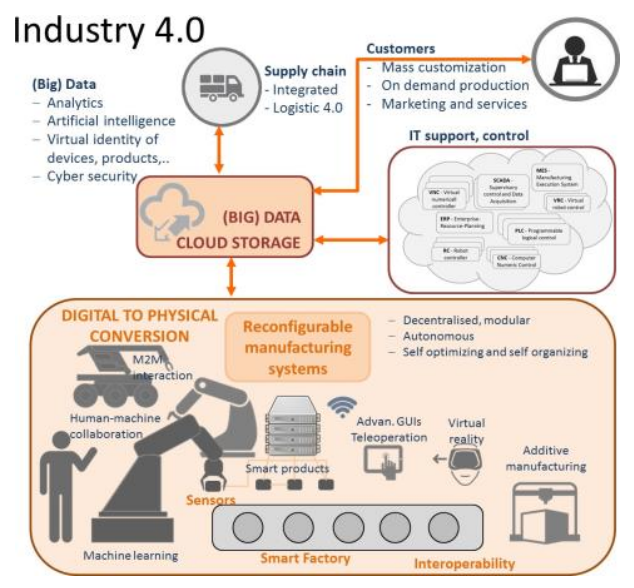

Gambar 2 Era Industri 4.0

Penggunaan big data menjadi suatu keharusan untuk dapat mengoptimalkan industri ini.
Dimana semua data dikumpulkan secara terintegrasi atau Blockchain untuk dapat dimanfaatkan guna kepentingan bisnis atau lainnya. (Dorri, Kanhere, \& Jurdak, n.d.; IBM, 2018; Pk, 2017; Rojko, 2017; Tieman \& Darun, 2017; Viraja, Kumar, Keerthi, Sandeep, \& Diagram, 2018)

Salah satu dampak era terakhir ini adalah penggunaan tenaga kerja manusia yang semakin sedikit dikarenakan sudah digantikan mesin. Sehingga persaingan bergeser menjadi manusia melawan mesin. Untuk dapat mengatasi hal ini, penelitian memfokuskan kepada Sumber Daya Manusia (SDM) berupa mahasiswa yang sedang melaksanakan pendidikan di bangku perguruan tinggi yang mengikuti kegiatan Unit Kegiatan Mahasiswa yaitu Resimen Mahasiswa (MENWA) sebagai salah satu UKM yang mengajarkan soft skill kepada anggotanya. Dan bukan kepada ICT atau mesin. (Info, 2015; Majid, Liming, Tong, \& Raihana, 2012)

Sejarah MENWA dimulai para pemuda, pelajar dan mahasiswa rela meninggalkan bangku sekolah mereka untuk mengangkat senjata yang dikenal dengan Tentara Pelajar (TP).

Kehadiran MENWA pada jajaran lembaga kepemudaan nasional di negara Indonesia bermaksud untuk dapat menggembleng para tulang punggung bangsa ke suatu arah kehidupan yang mengutamakan Pancasila dan UUD 1945 sebagai dasar dalam kehidupan berbangsa dan bernegara serta sebagai perwujudan Sistem Pertahanan dan Keamanan Rakyat Semesta (SISHANKAMRATA).

MENWA pertama kali dibentuk oleh Jenderal Besar A. H. Nasution pada masa Orde Lama (ORLA), perubahan-perubahan yang dilakukan oleh MENWA sebagai bagian dari reposisi, reorganisasi, dan refungsi organisasi MENWA terus dilakukan sebagai bagian dari reaktualisasi untuk memenuhi dan menyikapi fenomena bangsa dan negara ini, apalagi sekarang dengan berkembangnya tuntutan demokratisasi dan civil society. (Letjend. TNI. Waris, Prof. Dr. Armai Arief, MA, Irjend.Pol. Drs. Bambang Suparno, 2013)

Berdasarkan hasil pertemuan dengan POKJA MENWA, diputuskan bahwa dalam penataan kembali UKM MENWA dengan Surat Edaran Dirjen Dikti Nomor: 212/D/T/2001 tanggal 19 Januari 2001 yang berisi memberikan wewenang sepenuhnya kepada perguruan tinggi untuk mengatur 
MENWA dan mengacu pada KEMENDIKBUD Nomor: 155/U/1998 dan Surat Edaran Dirjen Dikti

Nomor: 208/D/T/2000 tanggal 30 Agustus 2000, dengan disesuaikan kondisi perguruan tinggi masing-masing. Pembinaan dan pemberdayaan MENWA dalam melaksanakan fungsi perlindungan masyarakat menjadi tanggung jawab Menteri Dalam Negeri dan Otonomi daerah. Namun demikian kunci pokok keberhasilan kegiatan MENWA akan sangat ditentukan oleh sikap keteladanan yang dipancarkan oleh MENWA itu sendiri. (Komando Nasional Menwa Indonesia, 2017)

Pendidikan soft skill seperti apa yang dibutuhkan oleh mahasiswa untuk memasuki era industri 4.0 menjadi latar belakang penelitian ini.

\section{METODE}

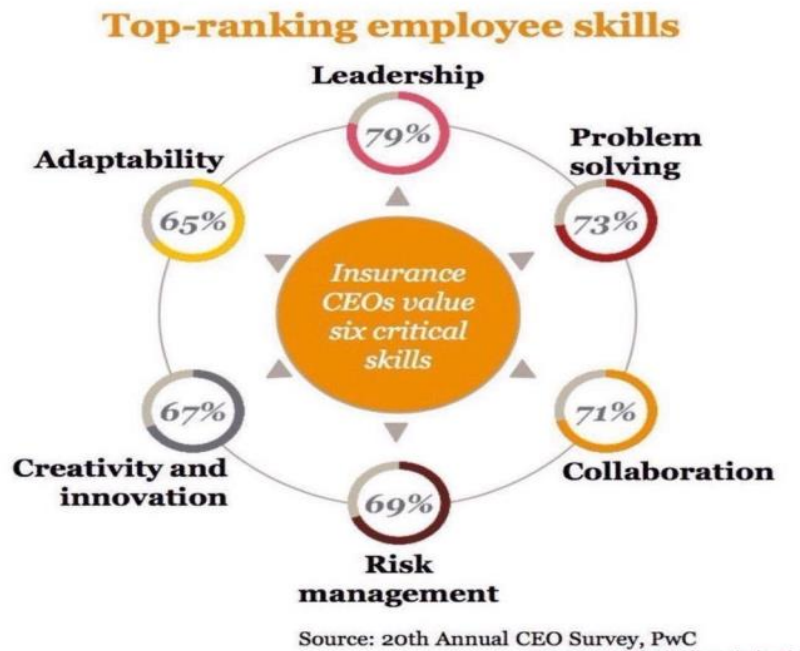

Menurut 20 $0^{\text {th }}$ Annual CEO Survey yang dilakukan oleh PricewaterhouseCooper ( $\mathrm{PwC}$ ) yang diinginkan dari seorang Chief Executive Officer (CEO) adalah:

(a) Leadership: $79 \%$

(b) Problem Solving: 73\%

(c) Collaboration: $71 \%$

(d) Risk Management: 69\%

(e) Creativity and Innovation: 67\%

(f) Adaptibility: 65\%

Dimana point (a) leadership merupakan salah satu bidang yang tidak bisa digantikan oleh robot atau automated machine lainnya. Hal ini juga merupakan competitive adavantage atau keunggulan

bersaing bagi lulusan perguruan tinggi. (Lauren, Fr, Lauren, \& Keywords, 1997)

Pendekatan yang digunakan adalah qualitative untuk menjelaskan peran aktif dalam meningkatkan character building. Teknik analisis data yang digunakan adalah menggunakan pendekatan yang dikembangkan oleh Miles dan Huberman yang meliputi (setelah pengumpulan data), yaitu mereduksi data, memisahkan data dari data yang tidak fokus, terlalu terperinci dan lain-lain sehingga data tersebut akan menampakkan pola atau tema.

Selanjutnya adalah menampilkan data yang berfungsi untuk membantu memahami analisis lanjutan terhadap suatu informasi atau event. Proses yang terakhir adalah penarikan kesimpulan yang dilakukan peneliti berdasarkan pola atau temanya. Penarikan kesimpulan dilakukan secara berkesinambungan, yaitu sambil dilakukan pada saat reduksi data dan tampilan data dilakukan.

Kunjungan telah dilakukan ke SKOMEN JAYAKARTA dan beberapa Satuan MENWA di DKI Jakarta dan Jawa Barat. (Miles, Huberman, \& Saldana, 2014)

\section{HASIL DAN PEMBAHASAN}

\section{MENWA SEBAGAI RESIMEN PENDIDIKAN CHARACTER BUILDING}

Seorang pakar management Henry Minzberg menyatakan cukup $10 \%$ saja yang mengerti Kontitusi Negara dapat memberikan $90 \%$ pengaman terhadap Kontitusi Negara, yang 10\% itu adalah para pemimpin yang mengerti dengan sungguh-sungguh Konstitusi Negara.

Pemimpin, berbeda dengan pengetahuan klasik yang mengatakan adalah dilahirkan, menurut pengetahuan modern dapatlah dibentuk. Pemimpin dapat diciptakan melalui pendidikan dan latihan, sekalipun tidak dapat disangkal bahwa seorang yang berbakat atau berjiwa pemimpin akan lebih mudah terbentuk tenjadi seorang pemimpin yang baik melalui pendidikan dan latihan. (Nguyen, 2018)

Di Indonesia, ada dua cara yang murni dan dapat didayagunakan untuk mempersiapkan pemimpin sipil yang mengerti dan setia pada Konstitusi Negara

$$
\text { Pendidikan }
$$


yang berlandaskan Pancasila dan UUD 1945. Kedua cara itu adalah dengan organisasi:

1) Gerakan Pramuka

Gerakan Pramuka adalah organisasi yang terkecilnya berada di TK, SD, SLTP, SMA/SMK dan di Pergurukan Tinggi. Mempunyai peringkat Siaga, Penggalang, Penegak dan Pembina. (Kwarnas, 2015)

2) Resimen Mahasiswa

Resimen Mahasiswa adalah organisasi yang terkecilnya berada di Perguruan Tinggi. Organisasi Gerakan Pramuka dan Resimen Mahasiswa yang berada di Indonesia berlandaskan Konstitusi Negara yang sesuai dengan Negara Kesatuan Republik Indonesia.

Kewajiban kepada setiap Perguruan Tinggi sebagaimana dijelaskan dalam Tri Dharma Perguruan Tinggi adalah Pendidikan, Penelitian dan Pengabdian Kepada Masyarakat. Salah satu kewajiban tersebut bagi institusi pendidikan adalah melaksanakan Pengabdian Kepada Masyarakat, hal ini dilaksanakan berkaitan dengan kepedulian setiap lembaga atau institusi yang bergerak di bidang pendidikan khususnya Perguruan Tinggi dengan mengikuti perkembangan dan kemajua teknologi, khususnya Indonesia sebagai satu negara yang memiliki potensi sumber daya alam dan manusia yang belum dapat disetarakan dengan negara-negara maju.

MENWA adalah Resimen Pendidikan dalam artian mengimplentasikan nilai-nilai bela negara bukan saja secara teori melainkan praktek sehari-hari dalam artian melaksanakan. Contohnya patuh pada peraturan kampus, dari hal-hal yang kecil, seperti datang tepat waktu, berpakaian rapi dan sopan, rambut rapi dan tidak gondrong, menjalankan Tri Dharma Perguruan Tinggi, menghormati sesama dan orang tua juga menentang segala ideologi radikalisme yang bertentangan dengan Pancasila. Luaran yang diharapkan adalah Sarjana plus serta generasi yang mengerti dan setia kepada Konstitusi Negara yang berlandaskan Pancasila dan UUD 1945.

\section{MENWA SEBAGAI KEUNGGULAN BERSAING DI ERA INDUSTRI 4.0}

Salah satu jalan untuk belajar memiliki leadership adalah dengan jalan bergabung dengan MENWA. Di UKM inilah mahasiswa diajarkan untuk menjadi seorang pemimpin. Dimulai dari menjadi bawahan yang baik.

Pendidikan MENWA dimulai dari Pra Pendidikan Dasar (PRADIKSAR), Latihan Dasar Militer (LATSARMIL) kemudian dapat dilanjutkan dengan Kursus Kader Pelaksana (SUSKALAK), Kursus Kader Pimpinan (SUSKAPIN). Juga dapat mengambil brevet kualifikasi seperti Mahir Menembak (HIRBAK), Scuba Diving, Helicopter Underwater Escape Training (HUET), terjun payung maupun kualikasi lainnya. Kesemua kegiatan diatas membutuhkan leadership, teamwork dan result oriented, sesuatu yang dibutuhkan dalam kehidupan pribadi dan bermasyarakat.

Penggunaan materi Peraturan Militer Dasar (PERMILDAS) seperti Peraturan Penghormatan Militer (PPM), Peraturan Baris Berbaris (PBB), yang diwujudkan juga dengan Apel Pagi, Penaikan/Penuruan Bendera Merah Putih, Kompi Markas (KIMA) menjadi keharusan untuk membiasakan disiplin sebagai nafas dari kegiatan yang dilakukan. Sehingga menjadi kebiasaan dan bukan kewajiban semata.

Hal yang sama dengan Kaizen yang dipopulerkan di Jepang. Kaizcn dikenal dengan $5 \mathrm{~S}$ atau Seiri, Seiso, Seiton, Seiketsu, Shitsuke dimana menjadi salah satu kunci keberhasilan Total Quality Management (TQM) dalam kehidupan pribadi maupun bisnis. (Gaspersz, 2007)

Akan tetapi, Kaizen atau $5 \mathrm{~S}$ yang sudah terbukti keberhasilannya, tidak akan berhasil tanpa $\mathrm{S}$ yang terakhir yaitu Shitsuke atau displin. Shitsuke menjadi nafas dan penentu keberhasilan Kaizen bukan karena menjadi kewajiban melainkan karena menjadi kebiasaan. (Gembakaizen, 2018)

Merujuk ke asal ilmu logistik yang berasal dari military science, dan ilmu transportasi yang membutuhkan zero defect dan zero human error, tentunya tidak sulit bagi kita untuk menghubungkan keberhasilan pendidikan dengan pembiasaan disiplin. (Bartholdi III \& Hackman, 2014; Bowersox, Donald J., Closs, David J., Bowersox, John C., Cooper, 2013; Christopher, 2016; Hendayani, 2011; Indrajit \& Djokopranoto, 2006; Raden Didiet Rachmat Simarmata \& Len Togas, 2015; Rizadly, 
Wynd, Hidayat, Raden Didiet Rachmat, Handayani, 2018)

Menilik peribahasa "the man behind the gun", maka "the man" menjadi poin terpenting untuk dilatih. Dalam hal ini, pembiasaan disiplin menjadi kata kunci dalam keberhasilan di era industri 4.0,

tentunya dengan tetap memperhatikan disiplin ilmu terkini, seperti Internet of Thing (IoT) dan Blockchain. (Dorri et al., n.d.)

\section{MENWA SEBAGAI RESIMEN PENURUN RISIKO RADIKALISME DI KAMPUS}

Sikap radikalisme tentunya sangat bertentangan dengan watak budaya Indonesia yang mengedepankan sopan santun, tata krama, musyawarah untuk mufakat dan menghindari caracara kekerasan dalam hal berbangsa dan berbudaya. Tidak mengakui Pancasila sebagai Dasar Negara Republik Indonesia menjadi persoalan yang serius ditengah kondisi masyarakat Indonesia yang majemuk dengan keberagaman suku, agama, ras dan antar golongan. Pancasila sudah final sebagai dasar negara yang dianut.

Lebih lanjut Menteri Riset, Teknologi dan Pendidikan Tinggi (Menrisetdikti) Mohammad Nasir mengemukakan harapan akan munculnya berbagai konsep akademik untuk melawan radikalisme yang diutarakannya dalam acara "Deklarasi Anti Radikalisme Perguruan Tinggi seBesuki Raya di Gedung Rektorat Universitas Jember, Rabu tanggal 27 September 2017 sebagai berikut:

"Di kampus, saya harapkan muncul berbagai konsep akademik untuk melawan radikalisme yang dihubungkan dengan pengembangan SDM secara sosial, ekonomi, dan budaya. Dengan cara ini kita dapat secara sistematis melawan berkembangnya pemikiran radikal dan mencegah terorisme," ujar Nasir. (Republik Indonesia, 2017)

Sebenarnya salah konsep akademik yang sudah ada dengan melibatkan mahasiswa secara aktif dalam bentuk MENWA sebagai salah satu pendeteksi awal gejala radikalisme di kampus. MENWA yang sudah menjalani pendidikan untuk setia kepada Pancasila dan NKRI, tentunya akan dengan mudah bergaul dan berbaur dengan mahasiswa lainnya, karena status MENWA yang memang mahasiswa, dan mendeteksi dini gejala radikalisme. Baik itu radikalisme kiri ataupun kanan. Bahkan disinyalir $23.4 \%$ mahasiswa di Republik Indonesia terpapar radikalisme. (detiknews.com, 2019)

Ditambah lagi dengan status MENWA sebagai UKM Khusus yang berada di bawah Rektor/Pimpinan Tertinggi Institusi yang

memudahkan jalur komando maupun informasi baik top-down maupun bottom up.

Menurut KBBI, yang dimaksud dengan radikal adalah radikal $^{1} / \mathrm{ra} \cdot \mathrm{di} \cdot \mathrm{kal} / \mathrm{a} \mathbf{1}$ secara mendasar (sampai kepada hal yang prinsip): perubahan yang --; 2 Pol amat keras menuntut perubahan (undang-undang, pemerintahan); 3 maju dalam berpikir atau bertindak; (RI, 2012)

Sehingga diharapkan tercipta bukan suasana radikalisme, melainkan suasana kondusif yang radikal dalam artian yang positif.

\section{KESIMPULAN}

Simpulan yang dapat diambil dari tulisan ini adalah: 1) MENWA sebagai resimen pendidikan character building, 2) MENWA sebagai salah satu pendidikan character building serta 3) MENWA sebagai resimen penurun risiko radikalisme di kampus. MENWA dapat berfungsi sebagai salah satu UKM yang melatih soft skill yang berguna di industri era 4.0. Karena leadership sebagai soft skill mempunyai nilai $79 \%$ sebagai yang diinginkan dari seorang CEO.

Saran yang dapat diberikan adalah dikeluarkannya keputusan pemerintah mengenai MENWA sebagai salah satu sarana pembelajaran character building melalui kegiatan organisasi mahasiswa dalam mendukung tercapainya keunggulan bersaing di era industri 4.0. Serta juga sebagai wadah mahasiswa untuk mengekspresikan diri dalam bela negara.

\section{REFERENSI}

Bartholdi III, J. J. \&, \& Hackman, S. T. (2014). Warehouse \& Distribution Science Release 0.96. Atlanta: The Supply Chain and Logistics Institute School of Industrial and Systems Engineering Georgia Institute of Technology.

Bowersox, Donald J., Closs, David J., Bowersox,

$$
\text { Pendidikan }
$$


John C., Cooper, M. B. (2013). Supply Chain Logistics Management (4th ed.). McGraw-Hill.

Christopher, M. (2016). Logistics \& Supply Chain Management. (5th ed.). Dorchester, UK: Financial Times/Prentice Hall.

detiknews.com. (2019). Menhan Sebut 23,4\% Mahasiswa di RI Terpapar Radikalisme. Retrieved September 13, 2019, from https://news.detik.com/berita/d-

4631020/menhan-sebut-234-mahasiswa-di-riterpapar-

radikalisme?tag_from=wp_nhl_cta_33

Dorri, A., Kanhere, S. S., \& Jurdak, R. (n.d.). Blockchain in Internet of Things: Challenges and Solutions.

Gaspersz, V. (2007). Fishbone Diagram. Jakarta: Prima Pustaka.

Gembakaizen. (2018). Kaizen Institute. Retrieved from https://in.kaizen.com/

Hendayani, R. (2011). Mari Berkenalan Dengan Manajemen Logistik. Bandung. Retrieved from http://cvalfabeta.com/0331-detail-

mari_berkenalan_dengan_manajemen_logistik .html)

IBM. (2018). Blockchain for Supply Chain - IBM Blockchain. IBM Blockchain. Retrieved from https://www.ibm.com/blockchain/industries/su pply-chain

Indrajit, R. E., \& Djokopranoto, R. (2006). Konsep Supply Chain (Cara Baru Memandang Mata Rantai Penyediaan Barang). Jakarta: Grasindo.

Info, A. (2015). Improving Students Soft Skills using Thinking Process Profile Based on Personality Types, 4(3), 118-129.

Komando Nasional Menwa Indonesia, K. (2017). Tentang MENWA.

Kwarnas. (2015). Gerakan Pramuka.

Lauren, P., Fr, I. U., Lauren, S. P., \& Keywords, C. (1997). The Porter's Theory Of Competitive Advantage, 3493-3498.

Letjend. TNI. Waris, Prof. Dr. Armai Arief, MA, Irjend.Pol. Drs. Bambang Suparno, D. (2013). Setengah Abad Menwa Jayakarta - Merambah Jalan Belantara Reformasi di Pusat Ibukota Negara. (Rasminto, Ed.). Jakarta: PPNI
Publishing.

Majid, S., Liming, Z., Tong, S., \& Raihana, S. (2012). Importance of Soft Skills for Education and Career Success, 2(2), 1036-1042.

Miles, M. B., Huberman, M. a, \& Saldana, J. (2014). Drawing and Verying Conclusions. Qualitative Data Analysis: A Methods Sourcebook, 275322. https://doi.org/January 11, 2016

Nguyen, P. (2018). On Henry Mintzberg 's Model of Managing, (September 2011).

Pk, S. (2017). Halal Supply Chain on Blockchain. Retrieved from https://www.linkedin.com/pulse/halal-supplychain-blockchain-shihabudheen-p-k/

Raden Didiet Rachmat Simarmata, J. H., \& Len Togas, N. (2015). Study on The Cause of Stock Out of Logistic Installation in Harapan Kita Hospital. Jurnal Manajemen Transportasi \& Logistik, 02(01), 79-92.

Republik Indonesia, K. R. T. D. P. T. (2017). Menristekdikti Minta Perguruan Tinggi Terapkan Strategi Baru Cegah Radikalisme di Kampus. Retrieved September 13, 2019, from https://ristekdikti.go.id/menristekdikti-mintaperguruan-tinggi-terapkan-strategi-barucegah-radikalisme-di-kampus/

RI, P. B. K. (2012). Kamus Besar Bahasa Indonesia - Kamus Versi Online/Daring (Dalam Jaringan).

Rizadly, Wynd, Hidayat, Raden Didiet Rachmat, Handayani, L. (2018). Manajemen Rantai Pasok Dan Logistik (1st ed.). Jakarta: In Media.

Rojko, A. (2017). Industry 4 . 0 Concept: Background and Overview. International Journal: Interactive Mobile Technologies, 11(5), 77-90. Retrieved from https://onlinejournals.org/index.php/ijim/article/viewFile/7072/4532

Tieman, M., \& Darun, M. R. (2017). Leveraging Blockchain Technology for Halal Supply Chains. Islam and Civilisational Renewal, 8(4), 547-550.

Viraja, K. S., Kumar, K. B., Keerthi, C., Sandeep, G., \& Diagram, A. B. (2018). IOT Based Smart Door System, 6(Iv), 438-443. 
Prosiding PKM-CSR, Vol. 2 (2019)

e-ISSN: 2655-3570 